\title{
Beyond the Job Ad: Employers and Library Instruction
}

\author{
Russell A. Hall
}

Many content analyses of job ads have revealed the skills and experience needed in academic library jobs and show that library instruction is an important job duty. This study moves beyond the content of the job ads and surveys the employers themselves (in the person of the supervisor). The survey revealed that supervisors highly value library instruction. Other findings relate to the types of instruction duties the new employee will engage in and the ways that these employees learn how to do library instruction, as well as how much time the employee spends on instruction-related duties.

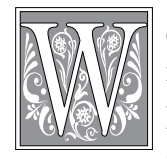

e often hear that instruction is an increasingly important part of academic librarianship. But what do employers think? How important are skills and experience in hiring for instruction librarian jobs? What kinds of instruction responsibilities will a new instruction librarian have? Where do instruction librarians gain these skills? Just how important is instruction to academic libraries? By surveying supervisors of instruction librarians, this study aims to investigate what employers look for when hiring an instruction librarian and their perceptions of the importance of instruction to their institutions. Further, the study will gain insight into how employers think librarians should gain instruction skills.

Over the years, many content analysis studies have been conducted using job ads for librarians. These articles are useful in establishing a snapshot of the library labor market at a particular point in time or measuring changes over time. Some have limited their samples geographically, while others have limited by type of job. However, these content analyses might not tell the whole story. The job ads only list the patent descriptions of the jobs, while there are many issues under the surface that may remain unanswered. As one group of researchers put it, "it must be acknowledged that a job advertisement indicates only what an employer explicitly says is required, rather than what is actually wanted or received." ${ }^{11}$ As a possible antidote to this problem, the current study was conceived to examine the perceptions of the supervisors of newly hired instruction librarians as well as the latent content of the advertised jobs.

This study seeks to go beyond just the study of the job ad to look at the mindset of the employers/supervisors who posted those jobs. By surveying supervisors, we can glimpse beyond just the text of the job ad and bring forth some other insights

Russell A. Hall is a Reference Librarian in John M. Lilley Library at Penn State Erie, The Behrend College; e-mail: rhall@psu.edu. (C) 2013 Russell A. Hall, Attribution-NonCommercial (http://creativecommons.org/ licenses/by-nc/3.0/) CC BY-NC 
into these instruction jobs and into the perceptions of these supervisors toward the job content.

\section{Literature Review}

Library instruction is an important part of library services. But how important and important to which jobs? Several studies have looked at these questions. Content analysis of job advertisements is the most common method to examine the importance of instruction in the recruitment of librarians.

Beverly Lynch and Kimberly Smith's 2001 article reported on their content analysis of 220 job ads in College $\mathcal{E}$ Research Libraries from 1973 to 1998 . Their study showed that "instruction had become an integral part of reference work." ${ }^{2}$ They found that, along with communication and behavioral skills (largely what have come to be known as "soft skills"), instruction had become a major component of frontline librarian jobs by the 1990s. Lynch and Smith noted that, at the time, not many LIS (Library and Information Science) programs provided formal education in instruction. They cautioned that "programs should look carefully at what kinds of teaching skills and learning theories should be included in the curriculum to meet the instructional responsibilities now found in jobs." Future studies (see below) continued to reinforce Lynch and Smith's findings and cautions.

Claudene Sproles and David Ratledge, in a 2004 analysis of entry-level job ads, found that "reference librarianship's large increase in bibliographic instruction data indicated that bibliographic instruction has recently become a major part of reference duties." ${ }^{3}$ Further, 64 percent of entry-level jobs from 2002 were in reference. Clearly, instruction is again found to be a key component of reference jobs, which are the most advertised jobs. Moreover, from 1982 to 2002, these entry-level job ads more than tripled in the number that asked for experience in bibliographic instruction. Sproles and Ratledge also note that "Graduate schools in library or information science could provide better preparation for their students by making practical library experience part of their programs."

In a 2005 study in the United Kingdom, Paula Younger found that nearly 25 percent of higher education library job ads asked for teaching and user education skills. ${ }^{4}$ Higher education also had the most job postings in the study. So again it appears that instruction is a very important part of the job of the average librarian, let alone the instruction specialist.

As seen in the aforementioned studies, the question often arises about where librarians should get their education and training in library instruction. Quite often, commentators feel that LIS programs should address these needs in their curriculum. However, there is certainly a place for professional development in teaching librarians how to teach.

As mentioned above, there has been continuing discussion regarding the roles of LIS programs in providing library instruction/information literacy courses. Studies such as Claudene Sproles, Anna Marie Johnson, and Leslie Farison's (2008) show that only 66 percent of students receive instruction in information literacy as part of required reference courses and that these courses only touch on some of the ACRL information literacy competency standards. ${ }^{5}$ Since the current study deals with instruction librarians, questions were asked about the importance of LIS programs in teaching aspiring librarians how to teach.

In Association of Research Libraries' (ARL) SPEC Kit 287, “Instructional Improvement Programs," Scott Walter and Lisa Janicke Hinchliffe surveyed ARL libraries to find out if they had programs in place to improve library instruction. ${ }^{6}$ This study moved away from library science programs being the source of learning for library instruction and instead examined "the activities that ARL member libraries pursue in order to assist librarians in becoming more effective teachers." In addition to "in-house" training, Walter 
and Hinchliffe also looked at methods for assessment and evaluation of instruction. They found that 63 percent of their respondents supported an in-house training program for librarians who wished to improve their teaching.

It can be seen that much of the previous research has used job advertisements as their launching point. But what about the actual hiring process? The job ad likely presents the job in terms of an ideal, rather than what the job and the candidate might actually do. This can sometimes be seen by looking at the list of preferred qualifications that are often given in addition to the required qualifications for the job. But what about the hiring process and what about the actual job behind the ad?

Zhonghong Wang and Charles Guarria's 2010 study of academic search committees sheds valuable light on the hiring process. ${ }^{7}$ Of particular importance to the current study, they found that more than three-fourths of public services candidates were required to give an instruction demonstration as part of the interview process. Also telling is that nearly a quarter of technical services candidates were also required to give an instruction demonstration. They also report that, for many jobs, experience is not necessary; more than 75 percent of the 227 respondents noted that they had hired a recent graduate with little or no library experience. Skills seemed to be a much more important factor "with combined ratings of extremely and very important reaching over $90 \%$." Intangible qualities such as personality and fit within the department are very important to the hiring process. Wang and Guarria found that these intangibles are more important than either experience or professional skills.

As members of the Education for Bibliographic Instruction Committee of the ACRL Instruction Section, Chris Avery and Kevin Ketchner produced a study in 1996 "on the perceived importance of library instruction skills to employers, and whether instruction experience or coursework is important in getting a job for which library instruction is a stated responsibility." 8 In this article, the investigators tried to look beyond the content noted in job advertisements. They conducted a telephone survey of academic and special library employers that had participated in the 1993 and 1994 ALA Midwinter Meetings' Placement Service. Since they were focused on library instruction, they limited the surveyed employers to those who advertised for a job that had library instruction as a job duty. Further, they excluded managerial and supervisory positions from their population. The telephone survey yielded 42 completed questionnaires from the supervisors. Supervisors were asked to rate the importance of instruction to their library, as well as the importance of instruction skills and experience to the position hired. Other questions asked the types of job duties the new hire would have, the best ways for a new librarian to learn instruction, inhouse training programs for instruction, whether instruction should be taught in library schools, and the percentage of time the new hire would spend on instructionrelated duties. Illuminating findings from Avery and Ketchner's study include the following: nearly 60 percent of respondents rated instruction as important or very important to the positions; 90.6 percent of the jobs require the new hires to spend between 5 and 30 percent of their time on instruction, with 10 percent of time being far and away the most common response; all but one respondent rated instruction as "important" or "very important" to their library. Avery and Ketchner also asked about what instruction-related duties the new hire would be involved in, such as one-time course-related instruction, coordinating an instruction program, or delivering credit courses.

\section{Methodology}

The intent of this study was to identify jobs posted for academic librarian positions that included instruction in their responsibilities, then surveying the supervisors for those jobs to see how 
much they value that portion of the job and what kind of skill and experience they look for in a candidate. This study draws heavily on the work of Avery and Ketchner. The instrument for this survey tried to capture all of questions asked by Avery and Ketchner and to add and expand a few items (see Appendix A). Unfortunately, Avery and Ketchner did not include a copy of their survey instrument in their article, so the wording of many of the questions had to be taken from the text of their article, which may not have been the same as the wording in the instrument. The current study asked questions about how long it took to fill the position; what section of the library the employee works in; and if this job is the new hire's first professional library job. These questions were not asked in the Avery and Ketchner study. Further, the current study expands on the earlier study's questions about library science program's teaching instruction; the value of "in-house" training for instruction; and how new librarians learn to do instruction. Also, the current study separated the importance of instruction skills and instruction experience in making the hire, where Avery and Ketchner had them lumped together. Another major difference from the Avery and Ketchner study is that they conducted their survey by phone, whereas this study used a selfadministered online survey. Also, the earlier study used job information from the ALA placement service at the Annual and Midwinter conferences. The current study collected job advertisements from the ALA JobList website. Also, the current study updated the language to "library instruction" rather than use the dated expression of "bibliographic instruction."

Job ads were culled from submissions to ALA's JobList website from all of 2009. Unfortunately, these ads are no longer available online. However, David Connolly of ALA was able to extract ads from their files that were labeled as "Academic/ Research" by the advertiser. The total number of ads retrieved was 1,016 . The ads were then examined by institution. Quite often, public libraries and public library systems posted jobs under the "Academic/Research" label. These were removed from the sample. The next step was to examine the jobs by title and duties. To limit the sample to "frontline" librarians, jobs that tended to be more managerial (usually positions such as Director or Dean) were removed from the sample. Some ads only included a link to a site where one could find the full job description. In almost all cases, these full descriptions were not available at the later date of this study. If the ad clearly indicated that the job had instruction duties, it was included. However, some jobs that may have had an instruction component were left out because of this. Due to the distinctive nature of archives and special collections, an attempt was made to try to remove these jobs from the sample. This is not to say that archives and special collections do not do a good job in library instruction; rather, it is that instruction in those subfields is significantly different from standard library instruction, so much so that their presence in the population might not have made for accurate comparison. Duplicate ads were removed from the sample as well. Last, the job ads all had to make explicit mention of an instruction component in the job. This criterion was included to keep in line with Avery and Ketchner, who looked at jobs that had instruction as a job duty and excluded supervisory positions. Applying all these criteria resulted in a final population of 216 job ads.

Ads from 2009 were used to generate a large population. More recent ads were not included because of the time lag in hiring for academic library jobs. ${ }^{9}$ By the time the surveys were sent to the employers, it was hoped that the preponderance of these jobs would be filled. Ideally, the supervisor would have had time to become well acquainted with the employee's skills but retain the details of the hiring process fresh in their minds. 
To determine whom to contact to take the survey, efforts were made to ascertain who the new hire's supervisor was. This was the same approach taken by Avery and Ketchner. An assumption was made here that the new hire's supervisor would have been on the search committee, if not the chair of that committee. Often the job ad would make this explicit, with text similar to the following: "Reporting to the Associate Dean for Collections..." In these instances, it was easy to go to the library's website and find the appropriate person to contact. When the ad did not make it clear who the supervisor would be, the staff list of the library was examined and judgment was used to determine who the likely supervisor was. For example, if the ad was for a chemistry librarian, the head of the science library was asked to take the survey. If the recipient was not the correct supervisor, he or she was asked to forward the survey recruitment e-mail to the correct supervisor. Due to several institutions having several postings during the year that reported to the same supervisor, there were 216 jobs in the survey but only 188 supervisors. Despite possible problems with the responses, it was decided to send a survey for each of the jobs advertised, meaning that some supervisors received more than one survey invitation, with the maximum being three. Surveys were administered online using SelectSurvey.NET (www. classapps.com/SelectSurveyNETOverview.asp) and distributed to supervisors via personalized e-mail. The survey instrument can be seen in Appendix A.

\section{Results}

From the 216 e-mails sent, two were returned as invalid e-mail addresses. Three job searches were cancelled or failed. This left 211 in the pool of e-mails; from that,
79 useful surveys were returned for a response rate of 37.4 percent. Geographically, the respondents were reasonably dispersed over the United States. Twentyfive percent were from the Northeast, 23 percent from the Southeast, 18 percent from the Midwest, 7 percent from the Great Plains, and 27 percent from the West. Most of the respondents were department heads (41\%), with director/head librarian (34\%) being the second highest response. Fifteen percent were Dean/Assistant or Associate Dean, 4 percent were coordinators, and 6 percent reported as other. The bulk of the respondents work in larger libraries, 44 percent with 11 or more full-time librarians and 35 percent with 6-10 full-time librarians. Seventeen percent were from libraries with 3-5 librarians, and only 4 percent were from libraries with only one or two librarians.

The vast majority of respondents reported instruction as being very important in their libraries and being important to the jobs that were advertised $(87 \%$ and $72 \%$, respectively; see figures 1 and 2). Sixty-five percent of the replies stated that instruction skills were a required qualification, 34 percent a preferred qualification, and only one job did not list it as either. Unsurprisingly, upwards of

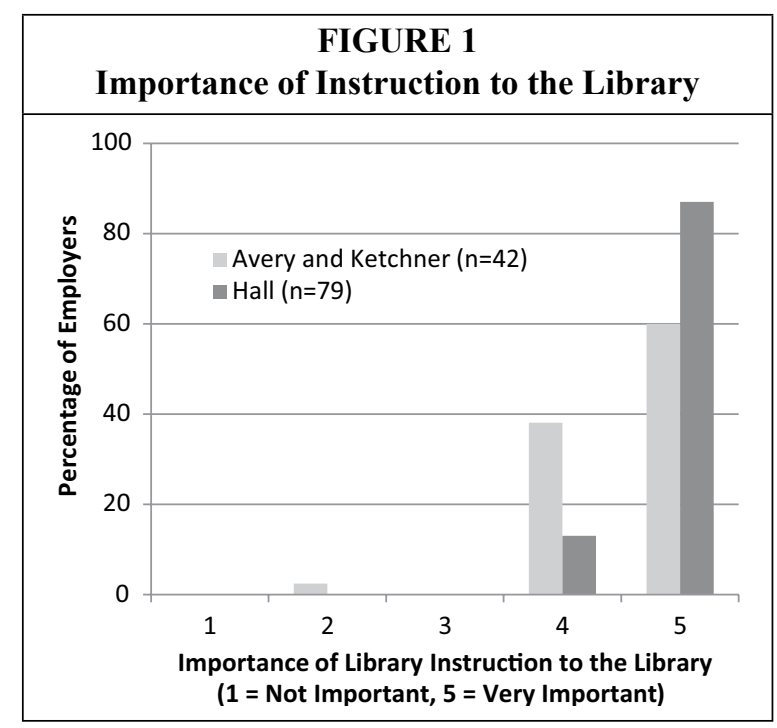




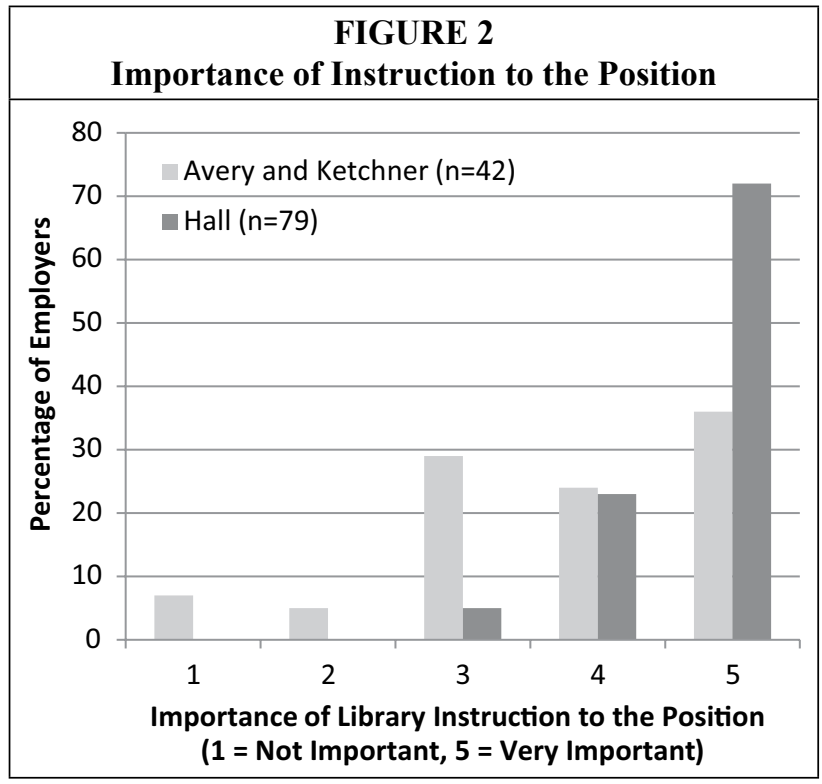

cent took longer than nine months. Surprisingly, 12 percent took 16 or more months to fill. Despite using slightly older ads to make sure that hires would have been made, eight of the 79 respondents indicated that the person hired for the position had not started working yet. Unfortunately, the question was not phrased to ask if a hire had been made at all. This is a small distinction, but perhaps an important one, since one of the goals was to have the respondent

90 percent of these jobs are in the public services sector of their library.

The majority of these jobs were filled within nine months, with 49 percent being filled in less than 6 months; only 29 per- look back on the hiring process. However, this is an improvement from Avery and Ketchner, where half of the jobs in their sample had not started working in their six-month time frame.

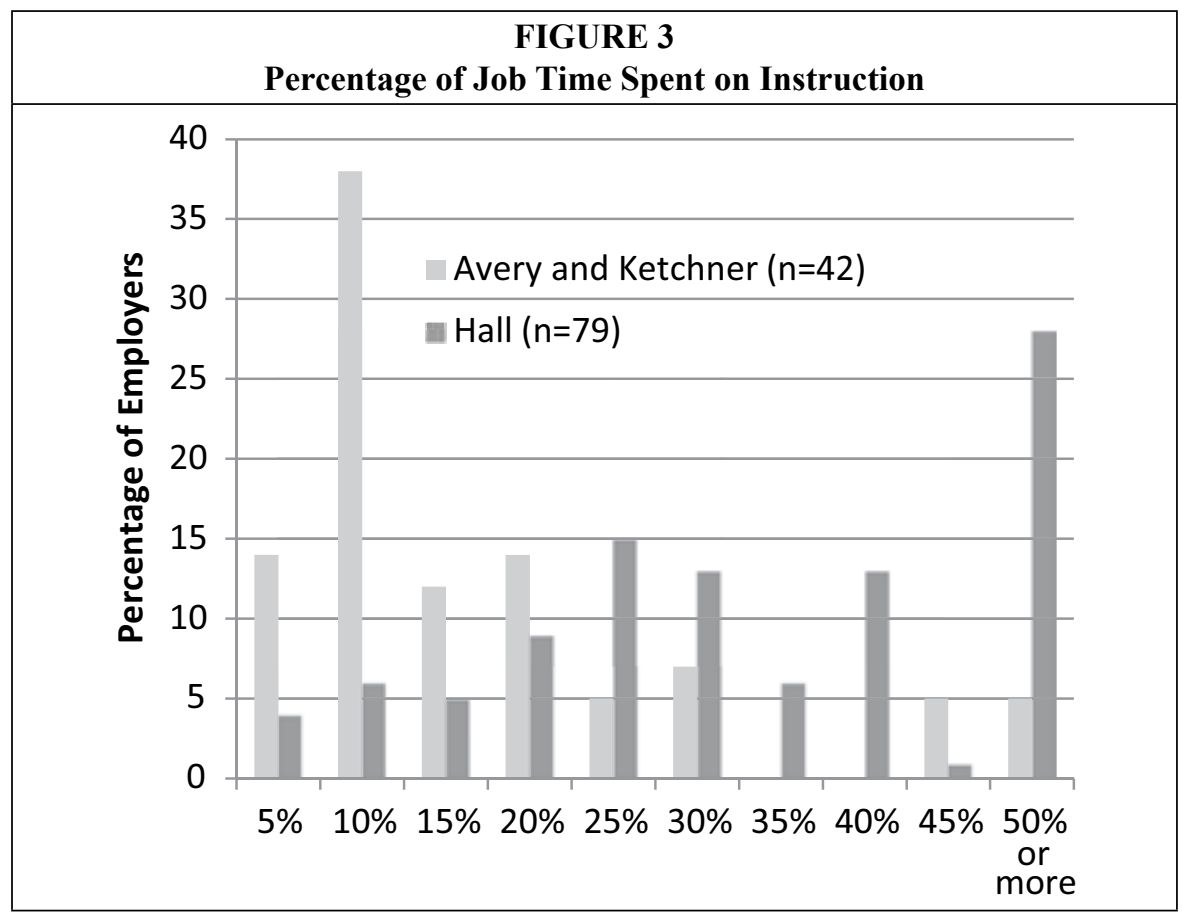


Perhaps the most important finding regards time spent on instruction duties. In a marked contrast to Avery and Ketchner's results, where only 4.7 percent of responses indicated that the job would require the employee to spend 50 percent or more of his or her time on instruction, the current survey responses indicate 28 percent of the jobs require the employee to spend 50 percent or more of his or her time on instruction. While the majority of the jobs in both studies require less than 30 percent of time in instruction, this skews more toward the upper end in the current study (see figure 3).

Another substantial difference from Avery and Ketchner was in how many of the new hires had to give a presentation as part of the job interview. The current study shows 96 percent of them had to give a presentation as opposed to only about half in the earlier report. Clearly, the ability to give a presentation is a standard practice for interviewing and hiring new instruction librarians, likely as a way to judge a candidate's public speaking and instruction skills since there is no way to determine these skills by looking at a resume or asking interview questions.

When asked what single factor was most important in making the hiring decision, the results varied widely. Often the respondent could not or would not reduce the decision to one factor. Representative responses were: "I cannot answer that question. The job is complicated, and the set of factors that were relevant cannot be reduced to an ordered list," and "There really isn't one single factor-it is truly a combination of experience, presentation skills, education, attitude, etc." Common responses were relevant experience, relevant skills, and personality fit. These responses match Avery and Ketchner's results.

The results included some good news for recent graduates. Respondents indicated that, for 39 percent of the librarians hired for these positions, this will be their first professional job after library school.

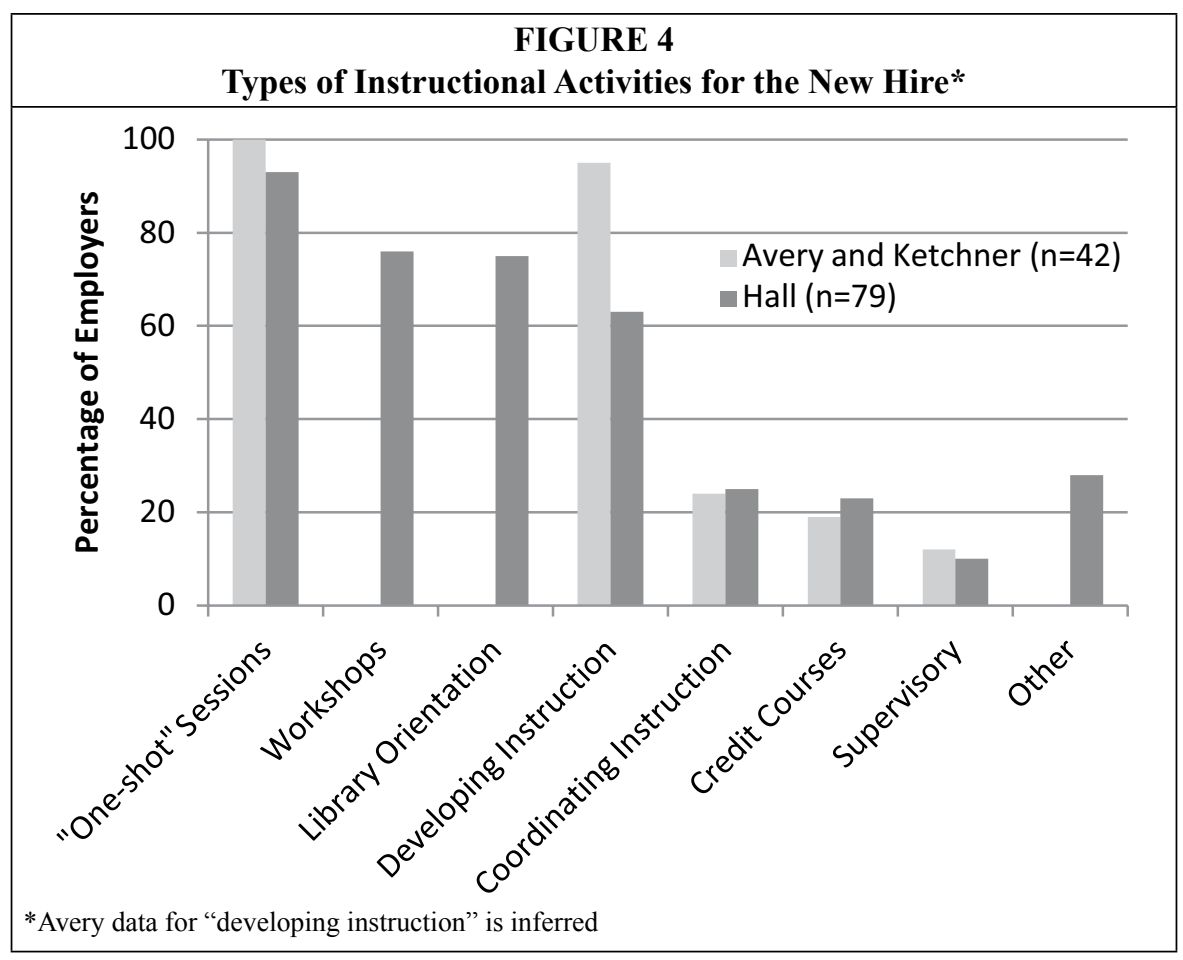


Surprisingly, it seems that skills were more valued than experience. Forty-nine percent rated instruction skills as very important and 32 percent as important, for a total of 81 percent. This is higher than the 63 percent who rated instruction experience as important or very important, with only 28 percent stating that experience was very important to the hiring decision. As long as a library school graduate is armed with the skills to do instruction, it appears that there are these types of jobs available in academic libraries.

New hires can be expected to perform a wide variety of instruction-related duties (see figure 4). As expected, the primary instructional duty is the "one-shot" course-related session. Many librarians will also be asked to present workshops on various library skills and tools, as well as to run library orientation programs. Interestingly, credit courses also have an important role in nearly a quarter of the jobs surveyed. Twenty-five percent of the jobs also involve coordinating a library instruction/information literacy program, while 10 percent of the total involves supervising other instructors.

On-the-job training and observation of other instructors were overwhelm- ingly the two most commonly reported ways that a new librarian learns to do instruction (see figure 5). This might be interpreted as the way to get important skills: to have a job where you can get experience. Other methods mentioned were these: reading the professional literature, ACRL Information Literacy Immersion Institute, previous teaching experience or education, and internships. On-the-job training and observation were again among the most frequently mentioned ways to best prepare a new librarian to do instruction, along with assisting more experienced instructors (see figure 6). "Other" was also a popular selection for how best to prepare a new librarian for instruction, and many of these were informative. Methods included: collaborative/team teaching, the ACRL Information Literacy Immersion program, and blending together multiple methods. "Other" was also popular because some respondents believe that there is no single best way to learn instruction, particularly depending on the strengths, background, and experience of the individual candidate.

Thirty percent of the respondents indicated that their library has a formal

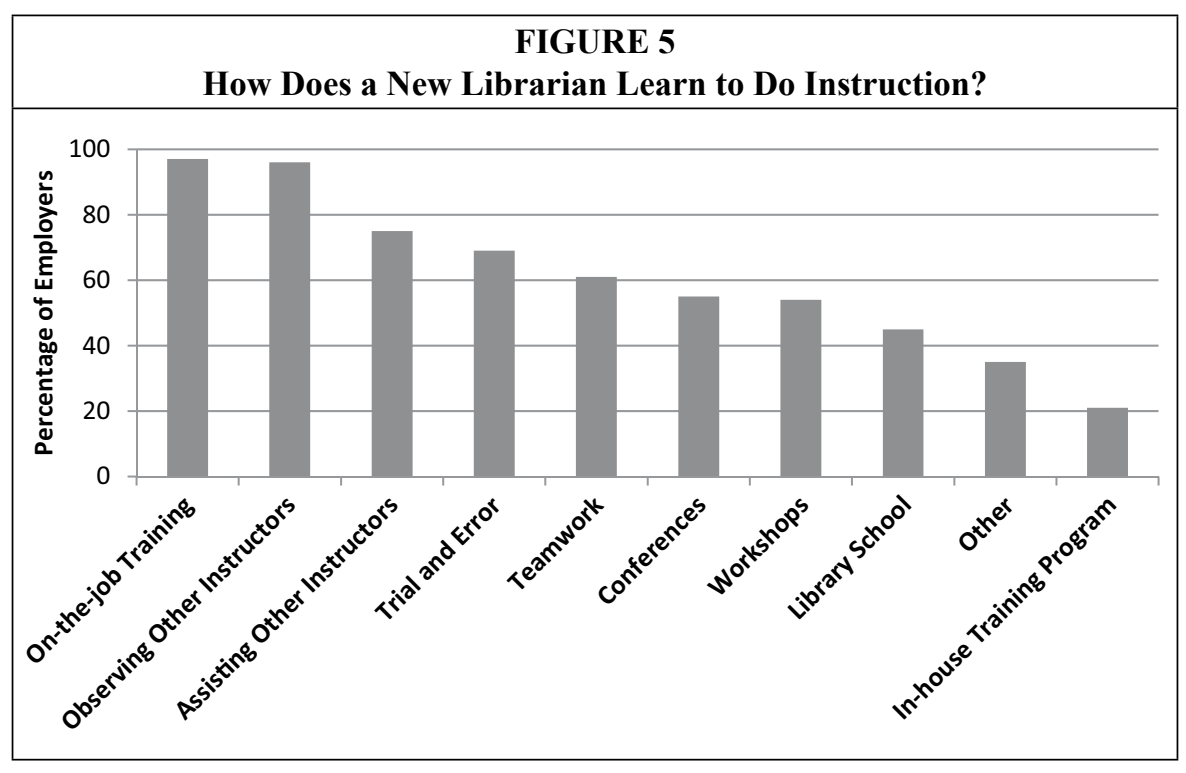




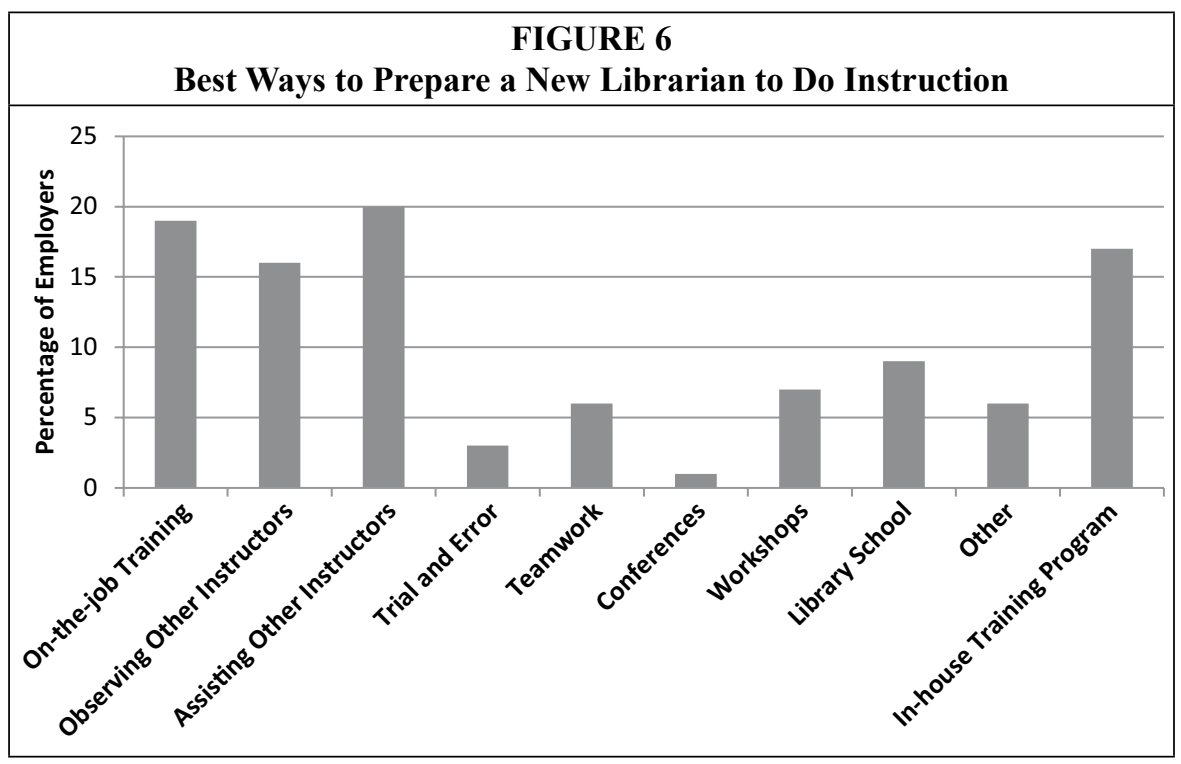

"in-house" training program for instruction librarians. This is very similar to the results found by Avery and Ketchner-roughly 33 percent-yet much less than the 63 percent reported by Walter and Hinchliffe. ${ }^{10}$ This finding is surprising because the supervisors realize that instruction is a very important part of public services jobs these days, yet there has not been a move to increase local training opportunities from the time of Avery and Ketchner's study. As to the large discrepancy between the ARL libraries in Walter and Hinchliffe's study reporting more than twice as many in-house training programs, this might simply be a function of the size and funding of the ARL libraries. Over half of the libraries in this study could be fairly characterized as small or medium in terms of their staff size. Time and funding might not allow for these smaller libraries to institute programs like those mentioned in Walter and Hinchliffe. For those libraries that don't have a formal instruction training program, opinion was very nearly evenly divided as to whether a formal program should be developed. Comments in favor of instituting an in-house program cited reasons such as:
"New librarians are thrown into the profession with very little instructional training. Librarians new to the institution may not be aware of our programmatic aims or of the tools we have at our disposal."

“To keep abreast of new instructional technologies, methods, techniques, approaches; to share knowledge and expertise among all instruction librarians; to better coordinate the overall instructional activities of the library."

"To ensure that librarians meet basic standards for classroom instruction techniques-how they present themselves, how they develop instructional materials, how they interact with classroom faculty, how instruction requests are responded to."

"Many of our librarians come in with no skills in instruction and many have been here for many years and never had training. It's good to get everyone to the same level in terms of their skills and knowledge base." 
The main reason for not having an in-house instruction training program is size and time. Many libraries see themselves as too small and too busy, "[f]ar too small a staff for far too large a population served with far too small a budget." Another respondent noted, "small staff size = everything we do is informal; which is not to say unimportant." Another reason given for not having a formal training program is that informal training seems sufficient and/or other means are taking care of it: "We have a very heavy mentoring program, but it is done on an ad-hoc basis depending on the librarian's need."

In contrast to the ambivalence about in-house training programs, 96 percent of respondents felt that instruction skills should be taught in library schools. This is a rather overwhelming number and should perhaps be contrasted with the fact that only one ALA-accredited program requires an instruction/information literacy course and that only 66 percent of library students get any introduction to information literacy in their required reference courses. ${ }^{11}$ The respondents did not claim that instruction should be a required course, but with a number that large it might be something for programs to consider. Many reasons were given for why instruction should be taught in library schools, including:

"For college libraries our delivery of information literacy curricula is becoming an essential and increasing component of who and what we are to our residential undergraduate population."

"As other skills and talents atrophy from the field of librarianship, information literacy and teaching become more and more important ... this is a growth field for librarians."

"The teaching role of libraries on college campuses is only growing in importance with the proliferation of information sources and technology

\author{
that makes access simpler-we need \\ prepared librarians."
}

\begin{abstract}
"The role of the librarian as teacher is of critical importance. If any library school student intends to work in public services after graduation, they will be called upon to teach in some capacity. These are foundational skills for our profession."
\end{abstract}

\begin{abstract}
"You can learn on the job, but that wastes a lot of time, both for librarian and students. [It] would be much better to enter the profession with a decent understanding of pedagogy in the field and having had a chance to develop skill, practice, and be critiqued."
\end{abstract}

Only three respondents answered that library schools should not teach instruction. The reasons given were that " library schools' are graduate programs in Library and/or information Science. Their courses should focus on the great content available in these areas. Pedagogy within those courses should develop the communication skills necessary to prepare students to engage effectively in library instruction in the workplace"; "On the job is too different from what could be taught in the curriculum"; and "Library Schools have many other basic things to teach graduate students besides educational theory and classroom management."

\section{Discussion}

As with any research done currently with job ads, their ephemeral nature in the electronic world poses problems. While the ads are able to be distributed widely and rather cheaply through electronic sources such as websites and listservs, they can be difficult to collect if they are not done while the job is open. As noted, the ads from ALA's JobList disappear after a certain amount of time, but there is an attempt (luckily for this study) to archive these documents. On other sites (like 
Rachel Singer Gordon's excellent Lisjobs. com), once the ad drops off the main page, it vanishes into the ether. Most listservs have archives of posts, but they are very difficult to search. The only way to make certain that all the job ads were retrieved would be to engage in the onerous task of going post by post through the archive. For others interested in researching job ads, it might be well worth it to collect the job ads from the listservs and/or websites as they appear and then save the data locally. This method would require a good deal of forethought and diligence by the researcher. Further, this study, and others of its ilk, rely on self-reported data and possibly suffers from the problems attendant with any self-reported information. Faulty memory, nonresponse bias, and social desirability bias could be possible problems.

As reported in several job ad studies, library instruction has become a large part of the job for anyone in public services. ${ }^{12}$ This study reinforces those conclusions. The finding that more nearly 90 percent of the respondents rated instruction as very important to their library is extremely telling. For the jobs in this study, not only is instruction a component of the job, but for more than half, it is the primary task. Again, to qualify for this study, the jobs only had to note an instruction component; they were not necessarily "instruction jobs." Despite this, more than 70 percent of respondents noted that instruction was very important to the position, and very few rated it as less than important. This speaks to the increasing primacy of instruction in public service jobs in academic libraries.

It is worrisome that many employers feel that the best way for new hires to get the training they need for instruction is through observation and on-the-job training. While undoubtedly this is an important part of any librarian's training and it is critical to find one's own teaching style to be effective, how much is lost by having an instruction librarian who is not at least grounded in the rudiments of pedagogy?
How much better could student learning outcomes be in the time period where the librarian was learning on the job? Is onthe-job training for instruction really one of the best methods for librarians to learn how to do instruction or is it simply the least costly in terms of dollars?

While clearly "one-shot" class sessions are still the bread and butter of the instruction librarian, it appears that other types of instruction are in demand such as specialized workshops and, perhaps most important, credit instruction. If the movement to integrate information literacy into the curriculum picks up more steam, it may move librarians toward even more credit instruction. Instruction librarians and their supervisors should take note and take steps to ensure that they are ready to meet this potential opportunity. Many respondents believe that the library school is a good place to start with developing instruction skills, and many believe the library school should do a better job of preparing librarians to do instruction. However, there are many other ways a librarian can improve and become better prepared to become an even better instructor.

In terms of preparation, instruction librarians should embrace professional development opportunities. The ACRL Information Literacy Immersion program was mentioned specifically by several respondents and is undoubtedly a tremendous learning experience. But, in addition to major programs like Immersion and national conferences, librarians should also take advantage of smaller, more local opportunities. Though a formal program may be too costly in terms of money and time, other more informal methods might be examined. The employers surveyed favored observation and assistance of other instruction librarians as among the best ways to learn instruction. This could certainly be extended to professional development. If not working with others in their own library or on campus, librarians could seek to make ties to other local colleges and universities and 
observe instruction in an entirely different institutional culture. This could only help to expand one's repertoire and lead to becoming a better instructor.

\section{Suggestions for Future Research}

There are several questions that this study raises, and many would be about instruction skills. The evidence suggests that employers may value skills over experience when it comes to instruction. But what skills, exactly, are the ones employers are looking for? From the current study's data, it looks like on-the-job training and observation are where employees are getting their instruction skills right now. Clearly this means that experience is necessary to get in the door to observe and/or train. Is this the best method? Should libraries invest in more and better instruction training for professional development? Who or what institutions should provide this training?

It would also be useful to expand this study to librarian jobs as a whole, rather than just instruction librarian jobs. Perhaps library supervisors in different departments (if the library is large enough to have departments) might feel different about the importance of instruction in his or her library. Comparing the findings here to the larger body of jobs would certainly be informative and could speak to the external validity of the findings of this study.

Finally, studies of the instruction librarians themselves would be instructive. One might study what skills and experiences the successful academic instruction librarian brought to the job interview. What knowledge, skills, and abilities did he or she perceive as the most important for the job? Where did they get their education and training regarding instruction? How important do they perceive that training to be? What do they think is the best way to "instruct the instructor?" Is there a difference in perceptions, skills, and training between new and established librarians? Clearly instruction is important to the set of library employers surveyed, and just as clearly there are no defined criteria for hiring an instruction librarian. However, there remains much to be examined about what makes the most successful library instruction job candidates and, one would hope, the most successful instruction librarians. 


\section{Appendix A. Survey Instrument}

1. How important is library instruction to your library?

$\square$ Not important $\square$ Not very important $\square$ Somewhat important

Important $\square$ Very important

2. How important is library instruction in the position you advertised for?

$\square$ Not important $\square$ Not very important $\square$ Somewhat important

Important $\square$ Very important

3. When hiring for this position, were library instruction skills required, preferred, or neither? $\square$ Required $\square$ Preferred $\square$ Neither

4. How much of their time (\%) will the new employee spend on library instruction?

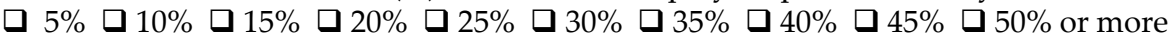

5. Has the person hired for this position started working yet? $\square$ Yes $\square$ No

6. Is this the new employee's first professional library position after graduating from library school? $\square$ Yes $\square$ No

7. From the time the position was vacated, approximately how long did it take to fill this position?

$\square$ 0-6 months $\square$ 6-9 months $\square$ 9-12 months $\square$ 12-15 months $\square$ 16+ months

8. What role did the candidate's skills related to library instruction and teaching have in your hiring decision?

$\square$ Not important $\square$ Not very important $\square$ Somewhat important

Important $\square$ Very important

9. What role did the candidate's experience related to library instruction and teaching have in your hiring decision?

$\square$ Not important $\square$ Not very important $\square$ Somewhat important

Important $\square$ Very important

10. What types of instructional activities will the new hire engage in? (Select all that apply)

口 "One shot" course-related sessions $\square$ Workshops $\square$ Credit course(s)

$\square$ Developing instruction and courses $\square$ Coordinating a library instruction (information literacy) program $\square$ Supervising other instructors $\square$ Library orientation programs $\square$ Other, please specify

11. Was the candidate required to make a presentation as part of the interview process?

ㄱes $\square$ No

12. What single factor was most important in making your hiring decision for this position?

13. Do you have an in-house training program for instruction librarians? $\square$ Yes $\square$ No

14. If your library does not have a formal library instruction program, do you think one should be developed? Yes $\square$ No 
15. If you answered yes to question 14, why should your library institute an "in-house" library instruction skills training program?

16. If you answered no to question 14, why shouldn't your library institute an "inhouse" library instruction training program?

17. What section of the library does this position generally work in?

$\square$ Technical services $\square$ Public Services $\square$ Administration $\square$ Other, please specify

18. In general, how do you think that a new librarian learns to do instruction? (Select all that apply)

$\square$ On-the-job training $\square$ Courses in library school $\square$ Observation of other instructors $\square$ Assisting more experienced instructors $\square$ Teamwork $\square$ Workshops $\square$ Conferences $\square$ In-house training program $\square$ Trial and error $\square$ Other, please specify

19. In general, what is the BEST way to prepare a new librarian to do instruction? (Select only one)

$\square$ On-the-job training $\square$ Courses in library school $\square$ Observation of other instructors $\square$ Assisting more experienced instructors $\square$ Teamwork $\square$ Workshops $\square$ Conferences $\square$ In-house training program $\square$ Trial and error $\square$ Other, please specify

20. Do you think that library instruction skills should be taught in library schools?

$\square$ Yes $\square$ No

21. If you answered yes to question 20, why do you think library schools should teach library instruction?

22. If you answered no to question 20, why do you think that library schools should not teach library instruction?

23. How many full-time librarians work in your library?

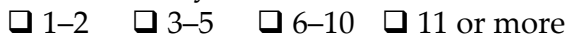

24. What is your role in your library?

$\square$ Director/Head Librarian $\square$ Dean/Associate or Assistant Dean $\square$ Department Head $\square$ Coordinator $\square$ Librarian $\square$ Other, please specify

25. In which region of the country is your library located?

$\square$ Northeast $\square$ Southeast $\square$ Midwest $\square$ Great Plains $\square$ West 


\section{Notes}

1. Mary Anne Kennan, Patricia Willard, and Concepción S. Wilson, “What Do They Want? A Study of Changing Employer Expectations of Information Professionals," Australian Academic $\mathcal{E}$ Research Libraries 37, no. 1 (Mar. 2006): 18.

2. Beverly P. Lynch and Kimberly Robles Smith, "The Changing Nature of Work in Academic Libraries," College and Research Libraries 62, no. 5 (Sept. 2001).

3. Claudene Sproles and David Ratledge, "An Analysis of Entry-Level Librarian Ads Published in American Libraries, 1982-2002," Electronic Journal of Academic and Special Librarianship 5, no. 2-3 (Fall 2004), available online at http://southernlibrarianship.icaap.org/content/v05n02/ sproles_c01.htm [Accessed 18 October 2010].

4. Paula Younger, "An Analysis of Skills and Qualities Required by LIS Employers, 2004-2005," Library \& Information Research 29, no. 92 (Summer 2005): 32-51.

5. Claudene Sproles, Anna Marie Johnson, and Leslie Farison, "What the Teachers Are Teaching: How MLIS Programs Are Preparing Academic Librarians for Instructional Roles," Journal of Education for Library and Information Science 49, no. 3 (Summer 2008): 195-209.

6. Scott Walter and Lisa Janicke Hinchliffe, ARL SPEC Kit 287: Instructional Improvement Programs (Washington, D.C.: Association of Research Libraries, 2005).

7. Zhonghong Wang and Charles Guarria, "Unlocking the Mystery: What Academic Library Search Committees Look for in Filling Faculty Positions," Technical Services Quarterly 27, no. 1 (2010): 66-86.

8. Chris Avery and Kevin Ketchner, "Do Instruction Skills Impress Employers?" College \& Research Libraries 57, no. 3 (May 1996): 249-58.

9. Wang and Guarria, "Unlocking the Mystery," 77.

10. Walter and Hinchliffe, ARL SPEC Kit 287, 13.

11. Russell A. Hall, "Exploring the Core: An Examination of Required Courses in ALAAccredited LIS Programs," Education for Information 27, no. 1 (Mar. 2009): 64; Sproles, Johnson, and Farison, "What the Teachers Are Teaching," 202.

12. For examples, see Kennan, Willard, and Wilson, "What Do They Want?"; Wang and Guarria, "Unlocking the Mystery"; and Jesús Alonso-Regalado and Mary K. Van Ullen, "Librarian for Latin American and Caribbean Studies in U.S. Academic and Research Libraries: A Content Analysis of Position Announcements, 1970-2007," Library Resources \& Technical Services 53, no. 3 (July 2009): 139-58.
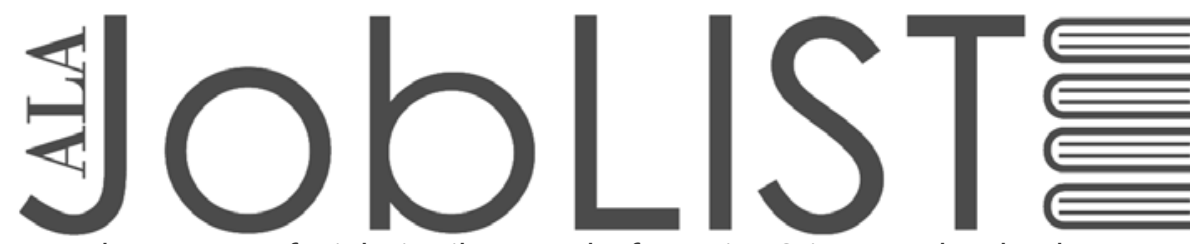

The \#1 source for jobs in Library and Information Science and Technology

\section{JOB SEEKERS}

Search and sort hundreds

of job ads by position type,

employer, location, and more

\section{EMPLOYERS}

Strengthen your candidate pool-

ALA reaches the most engaged

professionals and students

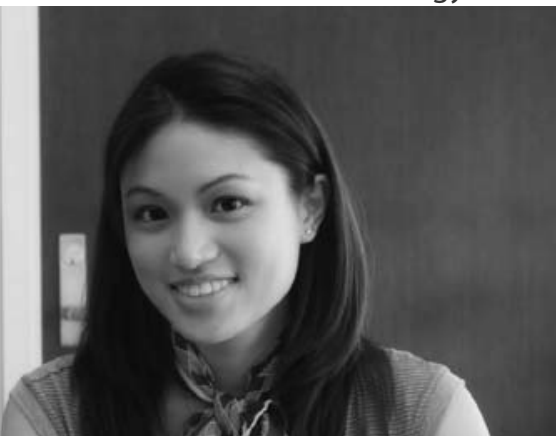

